Corresponding Author:

Sandra Aulia

Received: 8 June 2018

Accepted: 17 July 2018

Published: 8 August 2018

Publishing services provided by Knowledge

(c) Sandra Aulia et al. This article is distributed under the terms of the Creative Commons

Attribution License, which permits unrestricted use and redistribution provided that the original author and source are credited.

Selection and Peer-review under the responsibility of the 2 nd ICVHE Conference Committee.

\section{A Comparison of Disclosure Practice of the Activities of 3r in Japan, United Kingdom and Indonesia in the Context of Environment Regulation}

\section{Sandra Aulia, Chaerul D. Djakman, and Amelita Lusia}

Vocational Education Program, Universitas Indonesia

\section{Abstract}

Along with the increase in business competition and globalization, stakeholders not only demand a company's financial statements to make decisions, but they also require more information such as information on environmental performance. The information incorporated in the environmental performance of the company's business plan and strategy with the ultimate goal, that is, improving the company's corporate value to stakeholders. This study elaborates on the differences in disclosure practices of the application of environmental performance that are the activity of $3 R$ (Reduce, Reuse and Recycle) conducted in Japan, United Kingdom and Indonesia in the context of environmental regulations that exists in each country through all disclosures, that is the annual report, website and other separate report. This study used 30 data samples of listed manufacturing companies in each country. This study found that the existing environmental regulations in each country is affecting the implementation of the activities of $3 R$ that then affects the disclosure by the company. The activities of $3 R$ were encountered in the CSR Report, Environmental Report, SHE Report, Sustainability Report, Environmental Sustainability Report, Environmental \& Social Reporting. In Japan, the level of the activities of $3 R$ and the quality of information disclosure in the activities of $3 R$ is the highest, followed by the UK and Indonesia. Research reveals that voluntary case will cause the hidden information that were disclosed in the media.

Keywords: environmental performance, $3 \mathrm{R}$ activities, disclosure, regulation

\section{Introduction}

$3 R$ activities have often we hear in our daily lives today, even many companies that have applied. Starting from the development of business and industry are growing rapidly contribute to progress in the economic and technological, but also create greater environmental impact, and the company is required to be responsible for 
the environmental impact thereof [24]. Environmental issues in 1990 began to attract attention because of their influence on vehicle emissions, pollution, depletion of the ozone layer, toxic waste disposal, risk remaining goods, depletion of natural resources and climate change ([21], Gamble et al., 1996 in [27]). So the company is required to use limited natural resources more efficiently, produce environment-friendly products and carry out business activities to minimize the impact on the environment. Companies are constantly looking for ways to maximize the effectiveness of business processes by minimizing the impact on the environment, one that is by doing eco-efficiency [47]. Ecoefficiency increased by activities that create economic value in a sustainable manner by reducing the ecological impact and the use of natural resources [16]. One of the main aspects of the eco-efficiency by performing the Reduce, Reuse and Recycle (3R). $3 R$ concept in a production process is able to save costs and protect the environment (Grant el al. 1999).

Concern for the environment is actually arise from a variety of encouragement from outside the company (Berry and Rondinelli, 1998). State plays an important role in environmental issues. The government faces pressure to make policies relating to environmental issues. Governments in many countries to make regulations in order to safeguard the environment so that business face higher pressure to run their operations in a responsible, transparent and honest (Darwin, 2007). Needs of increasingly high for the company to disclose information about the performance environment becomes higher ([5], in the Dunk, 2002). Several previous studies have assumed that environmental regulations make companies spend a lot of money every year to comply with these regulations (Portney \& Stavins, 2000 in Darnall 2008), so that regulations detrimental to the economic performance of companies or inhibit financial opportunities (financial opportunities) Companies [7, 8, 34]. Meanwhile, some other researchers say that the regulations regarding the environment it provides a boost for companies in developing innovations to reduce environmental impact and improve efficiency [41]. So that environmental issues make each country is increasingly developing and tightened standards or regulations that must be met by the company. And to meet these standards, companies are required to understand the environmental impacts of the products and the company should try to create a product that is environmentally friendly and can use limited resources effectively, and continues to innovate exploring alternative sources of production efficiency.

Along with the increased competition and globalization, stakeholders not only requires a company's financial statements to make decisions, but they need more 
information as well as information about the environment. And managers have incentives to improve environmental disclosure to influence the good response from social agencies such as regulators, pressure from specific groups, and others, and in choosing the disclosure strategy, managers have to trade-off gains from the disclosure of the extent of the adverse costs may result from such disclosure [3].

Many companies that have been doing the activity revealed in detail in the websites, annual reports or other separate environmental reports, such information would provide better knowledge to stakeholders. Environmental information included in the company's business plan and strategy with the ultimate goal of improving the company's corporate value to stakeholders. Several previous studies say that the attitude friendly to the environment (environmental friendly attitude) can improve efficiency, boost stock prices, strengthening brand value and increasing competition [41, 47]. Companies that improve environmental performance will improve market prospects, and creates an advantage in the competition (Hart and Ahuja, 1996; [32, 42, 44] in [12]).

\section{Literature Review}

\subsection{Economic theory related to the disclosure}

Some theories used in relation to the disclosure of which is agency theory, signaling, and litigation [20, 21, 23, 40,43]. First, agency theory, which says that the shareholders will make price-protect to avoid fraud committed by management. So to avoid this, the voluntary management of the company took several measures, including disclosure $[6,29,33,37]$. In this case the management would do regarding the disclosure of $3 R$ activities to avoid asymmetry of information for shareholders. Second, signaling theory, saying that voluntary disclosure is the purpose for the company or manager to distinguish themselves from the other woods, such as the quality and performance of the company. Third, the theory of legitimacy [17], the disclosure of social meaning 'deal' to political pressure and social (Lindblom,1992; Patten, 2000, in M. Freedman, B. Jaggi (2005). The company is part of the purpose social. by disclosing environmental information, companies are trying to convey to stakeholders that they meet environmental and social objectives, and to reduce public pressure. So the company will legitimize their performance with environmental and social disclosure (Lindblom, 1994 in the M. Freedman, B. Jaggi, 2005). Guthrie and Parker (1990) states that the disclosure of environmental and social "Appeared to reflect public social priorities, respond government pressures and sectional interests and protect corporate prerogatives and projected 
corporate image." Companies that understand that their responsibility is not limited to producing cheap goods, but also provide benefits to the environment and the company itself, such as the positive feedback form the brand image or a good corporate image, one of the benefits [30]. If developed properly, then the activity of the 3 Rs by the company will create an emotional connection between the company which will have an impact on brand awareness, and over time will develop into brand loyalty that will create brand equity that is profitable for the company as it says in CSR research by Temporal and Trott (2005) in Mawarsari (2006). Organizations that have a high environmental commitment by producing green products will gain market benefit ([32], in [12]). The legitimacy of many theories tested in several empirical studies and the results are consistent with the theory. Many studies using a sample of companies in the US $[39,40,49]$, research the legitimacy of a sample of companies in Europe among them [2], a sample of companies in Australia namely Deegan \& Gordon, 1996, Deegan and Rankin, 1996), and a sample of companies in Indonesia that Nurhayati, Brown and Tower (2006). All research results are consistent with the theory of legitimacy. So based on the results of previous studies, the authors assume that the disclosure of information on the $3 R s$ in accordance with the legitimacy of the model.

Environmental issues to the attention of researchers and professionals during the past few years, such as in research Wiseman (1982), Guthrie and Parker (1990), Harte and Owen (1991), Gambel et al. (1995), Gray et al., (1995a), Gambel et al. (1996) and Deegan and Rankin (1996), Williams (1999), L. Holland and Boon Foo (2003); Cormier and Magnan (2003), James et al. (2006), Aerts et al. (2006). Several studies provide empirical evidence related to environmental issues both in America and in other countries. Hackston and Milne (1996) investigated the social and environmental disclosure for companies in New Zealand, and the findings indicate consistency with previous research for the US, UK (England) and Australia, environmental issues have become a significant concern.

\subsection{Recycle, reduce and reuse (3R)}

Viewed from the standpoint of natural resources (resources), there are so-called nonrenewable resources are natural resources that cannot be updated to run out sometime and renewable resources are natural resources that can be renewed. Those resources are increasingly limited and diminishing in number, so must be made savings through three steps, namely the reduction of the use (Reduce), the re-use (Reuse) and recycling (Recycle) which is known as the 3 Rs [31]. From the standpoint of corporate 
responsibility towards the environment, $3 R$ is one of the company's commitment to the environment, which is an effort to minimize the negative influence of the environment caused by the products produced by the company. But to be a responsible company (CSR company) not only ensures that the waste material is collected and recycled, but the company must look at the issues surrounding the $3 \mathrm{Rs}$ in the context of that further.

Research in developed countries shows that the use of the $3 R$ concept in the production process of a product capable of saving costs and protecting the environment better. For instance, recycling glass or glass can save energy up to $74 \%$ compared to glass or glass to make products from raw material origin (Grant et. al., 1999). By doing $3 \mathrm{R}$ means reducing the amount of virgin natural resources are used and also assist efforts in climate change, for example, every ton of paper in the recycle can save 17 trees, this means saving resources are limited, and the tree can absorb $\mathrm{CO}_{2}$ from the atmosphere so it's also an attempt to tackle climate change. 1

Recycle is to recycle useful components through additional processes that produce the same product or different products. Example: recycle successfully conducted by Nissan in Japan, which was initially a difficult thing to do. Nissan managed to use plastic water bottles to be used as the main component in sound insulation layers on the dashboard and floor insulators. Recycling can save energy, space and cost of the use of these materials to be made into new products. Reuse is the reuse of products which have not been used for the same purpose without going through an additional process. Reuse (reuse) means wearing the same item more than once. The concept of reuse or reuse can save resources that may be used to make new products. Examples in the UK, Morgan Crucible Company is ceramic companies in the production process to produce steam and steam with new technologies such as electric energy used directly without any further processing. Companies that do not pay attention to environmental issues will have a negative impact on the environment in the form of waste disposal into the air through the chimney, causing air pollution, to perform environmental management system that is good in a way to reuse the company is already doing ecoefficiency is to improve efficiency while reducing impact environment arising from operating activities. Activities reuse conducted Morgan can produce efficiencies in the form of savings of 69 thousand $\mathrm{kWh}$ of electricity while reducing $\mathrm{CO}_{2}$ emissions per unit electrochemistry. Reduce is reducing component that could potentially produce waste or by reducing the product, reducing the amount of material used for the production, reducing the time, design, the amount of inventory, product size and others. In its implementation if the waste can in the recycle and reuse it should reduce. 


\subsection{Regulatory conditions of a country}

Concern about the environment is becoming a global phenomenon, but the rate of the concern varies ([18,43] in the [25]). Many factors make managers of companies in different countries will be more or less attention to environmental issues, one of the factors that regulation, governmental actions, national culture and economy, pressure from certain groups, or the number of environmental problems arising $([36,45]$ in [25]). Williams (1999) examined the voluntary disclosure about the environment in the Asia-Pacific and found significant differences in the disclosure for companies operating in each of the State, the dimensions of the country and the political system as well as civil a country largely determines the quality of information on environmental disclosure and social of each country. Gamble et al. (1995) examined the environmental disclosure in the annual report on 9 industries and 27 countries for the years 1986 to 1991, the results showed that companies operating in the country that have high levels of social and/or capital markets are developing will be more revealing information about the environment, and the United Stated (US), Canada and the United Kingdom (UK) has the highest level of disclosure. Vanstraelen et al. (2003) tested the disclosures made by European countries such as Holland, Germany and the UK, their research focused on six categories: environment around the company, the environment within the company, strategy and management, the trend of the company, production and customer. Craig and Diga (1988) analyzed the disclosure in the annual report in five (5) ASEAN countries namely Singapore, Malaysia, the Philippines, Indonesia and Thailand, the results indicate that, overall, the company ASEAN looks reluctant to disclose information that is considered sensitive to the political and social such as the activity of labor, government subsidies and also the company's programs on the environment. So it can be said that the reporting company to the ASEAN countries are very oriented to the information required for the provider of capital, compared to the information needed for a wider stakeholder (including the government, employees and other public community).

It can be said that, many empirical studies regarding the environmental focus on the State of USA, Canada, Australia, New Zealand, The United Kingdom, and other European countries. Few studies that examine this issue for Asian countries except Japan. Thus this study attempts to further research on the 3Rs activities of the company, using the State of Japan (as the number one economy Countries in Asia and around the world and the country are very concerned about the environment and climate change) Li-Chin et al. (2007), European countries, namely Britain is a European country who care about 
the environment and have a level of disclosure that is higher (Gambel et al., 1995) and according Hackston and Milne (1996) issue of the environment has a significant attention to the European countries, as well as the State Indonesia, which is rarely sampled in international research on the environment and have the environmental disclosure is still very low [Nurhayati, Brown and Tower (2006)]. This study uses the state of Japan, the UK and Indonesia as samples, each of which have differences in culture, laws and regulations related to the activities performed $3 \mathrm{R}$ and disclosure.

\subsubsection{State environmental regulation Japan}

Japanese country has an excellent reputation for his success in addressing issues of energy use and pollution in the 70 and 80 s. Last year, Japan took an important step in making environmental policies related to eco-efficiency. A focus on waste and recycling issues, which are driven by the limited capacity of the land owned and the need for import of natural resources. Activities undertaken Japan is $3 R$. The goal is a recyclingoriented society (Junkankata Keizai). (Raimund, n.d.)

Parliament in Japan has issued a regulation in May 2000, the Basic Low for the Promotion of Recycling-Oriented Society, Waste Management Law, the Law for Promotion of Effective Utilization of Resources, Construction Materials Recycling Law, Food Recycling Low and the Green Purchasing Low. Coupled with the Containers and Packaging Recycling Law (contains minimum recycling obligations) and Home Appliances Recycling Law, and issued regulations in 2002 that Automobile Recycling Low (regulation requesting automobile industry companies collect and recycle ASR, chlorofluorocarbons, and airbags), and in 2005 issued End-of-Life Vehicle Recycling Low.

In January 2001, the Environmental agency that is transformed into the Ministry for the Environment ([46] in Bleischwitz, n.d.). The new ministries are responsible for the basic questions about environmental policy, environmental basic plan, waste, water and air pollution, nature protection and biological diversity, liability for any damage, and international cooperation environment (e.g., climate change). While the Ministry for the Economy (METI) still has the authority to chemicals and hazardous substances, recycling, a measure to combat global warming, and environmental influences test.

In the study Li-chin and Martin (2007) said the Japanese Ministry of the Environment and the Japanese Ministry of Economy, Trade and Industry published a guideline in preparing the report on the environment. Guidelines issued Recycling include design guidelines (Ministry of Economy, Trade and Industry). The government has also issued guidelines for environmental disclosure 'Environmental Reporting Guidelines' (version 
Fiscal 2007), published by Japan's Ministry of the Environment. Many companies are also making a report based on the guidelines issued by the GRI is 'Sustainability Reporting Guidelines'.

Japanese capital market also took the top environmental concern by issuing a CSR index is TOPIX 1000 CSR. And reward the efforts of companies concerned with the environment both in terms of innovation, technology and other achievements such as Excellent Energy Management Plant Awards (issued by the Ministry of Economy, Trade and Industry), Award for 3R, Sustainable technology issued by the cleans Japan Center, 3R Promotion Persons of Merit Awards (3R Promotion Association) and others.

Although environmental reporting is not required mandatory, but many companies in Japan published the reports. Seen from the amount of disclosure about the environment is growing rapidly and the disclosure of the content is updated annually 2 .

\subsubsection{Environmental regulation of the United Kingdom}

National environmental low in the United Kingdom including the impact of the European Union Low and International Low that includes attention to the control of environmental degradation. Environmental laws also control air and water pollution problems. In 1980, the control of air pollution from new industry developed, and the concept of 'best practicable means' introduced to control the problem of hazardous substances in the environment. However, in some recent years, the old rules have been consolidated into a more broadly as the Environmental Protection Act 1990. The force of law is also increasing. Companies that neglect to environmental protection can be prosecuted and fined for environmental damage arises. The main feature in the Environmental Protection Act 1990 is the Integrated Pollution Control (IPC), and the purpose of IPC is to minimize the whole environmental impact caused by introducing the concept of 'best practicable environmental option' or the so-called (BPEO) and also the concept of 'best available techniques not exceeding excessive cost' (BATNEEC) which replaces the previous concept of 'best practicable means'. To ensure compliance with BPEO and BATNEEC, companies must take some action such as leveraging new waste treatment, investments in new processes and create technology that can do improvements to emissions. This may lead to the higher capital expenditure in order to adhere to the environmental laws. It is said in the research and Boo Foo Holland (2003).

In addition to the Environmental Protection Act 1990, other regulations issued by the government, namely the European Union REACH regulations, European regulations 
on the Restriction of Hazardous Substances (RoHS), Waste Electrical and Electronic Equipment (WEEE). End-of-Life Vehicles Regulations 2003 statutory instrument 2003, No. 2635 issued by the Department of Trade and Industry, Packaging Waste Regulations targeted for recovery and on packaging waste recycling, and so forth.

Britain has a variety of guidelines on environmental reporting such guidance for compilation of reports on greenhouse effect gas emissions (1999), guidance for the compilation of the report on waste emissions (2000), and general guidance for environmental reporting (2001). Research Holland and Boon Foo (2003) said that the European countries have to have environmental regulations that are well developed. Besides the capital market also plays an important role in the FTSE4Good UK index as a benchmark for the size and performance of companies that have met the standards of corporate responsibility.

\subsubsection{State environmental regulations Indonesia}

The Indonesian government has accommodated the importance of awareness of companies on the environment by issuing Law No. 40 Article 74 of 2007 regarding the limited liability company one of the articles in it stipulates that the company's business activities in the field and/or related to the natural resources required to implement social and environmental responsibility 3 . In 2009, the government issued a re Act No. 32 of 2009 on the environment in more depth. The law has to accommodate the implementation of an environmental management system properly, including explaining and regulating the environmental audit. UU no. 32 in 2009 is the essence of the application on the environment in many countries and can be used as a guideline for companies to implement an environmental management system. In addition, the government has also issued a law in accordance with the industrial fields such as Law No. 7 of 2004 concerning the fields of water, Law No.41/1999 governing the forestry sector, and others.

Associated with 3R, Ministry of Environment of Indonesia also issued regulation No. 2 in 2008 regarding the use of hazardous and toxic waste, contains an appeal to implement $3 R$ activities. The Indonesian government also routinely assessing adherence to applicable laws and sanctions for any violations. And the government gives awards to companies that have met the proper prerequisites such as environmental awareness, adipura, blue sky, and PROKASIH. 
PROPER is level of corporate performance assessment programs in environmental management since 1995. PROPER is Public Disclosure Program for Environmental Compliance, so that environmental quality can be delivered more efficiently and effectively. Objective implementation to improve the compliance of companies in environmental management, increasing the commitment of stakeholders in efforts to conserve the environment, improve the performance of sustainable environmental management, raise awareness of businesses to comply with legislation on environmental issues, encouraging the application of the principles of Reduce, Reuse, Recycle (3R) in waste management.

The Company is also obligated communication of environmental information management is doing, in accordance with Law No. 23/1997 Article 6, paragraph 2: "Everyone who conduct business and/or activity must provide true and accurate information about environmental management." However, Disclosure $3 \mathrm{R}$ done voluntarily and there is no specific guidance disclosure of information issued by the government as well as in Japan and European countries.

Indonesian stock exchange has also issued stock price index, which refers to the CSR that is SRI-KEHATI in June 2009, the capital market was created as additional guidelines to encourage sustainable business through a method based on environmental awareness. However, this index is an index of the Indonesia Stock Exchange cooperation with the Foundation for biodiversity and not Bapepam issued.

Many companies in Indonesia who have been doing CSR activities but not many reveals in a report (Darwin, 2007), including the $3 R$ activities. Financial Accounting Standards Indonesia is also not required companies to disclose social information, especially information on corporate responsibility towards the environment, so that the information disclosed voluntarily.

\section{Research Methodology}

The study was a cross-country (cross country). This research data is web-base, all data obtained from the website, good information on the 3Rs, ISO, environmental reports, sustainability reports, CSR reports, SHE reports, annual reports and financial data Osiris in down-loaded from the website. 


\subsection{Selection of samples}

The research sample is Japan, the UK and Indonesia. Japan, for a number of indecent economies in Asia and around the world and is a country that is concerned about the environment [35]. English country because it is a country that has a powerful economic force and many of his company that operates throughout the world, have environmental regulations are progressing well, said in Holland and Boon Foo (2003). According Hackston and Milne (1996) issue of the environment has a significant concern in European countries. State of Indonesia as a country that is rarely examined in international research on the environment and according to Craig and Diga (1998) companies in Indonesia less revealing information about the environment and nurhayati, Brown and Tower (2006) says that the level of concern for the environment at the company in Indonesia is very low. Listed companies in each country using available data on Osiris. Companies that were sampled only companies from the manufacturing industry (Theodore, 2004). Companies that do not have an annual report on the website are not included in the sample. Period of observations conducted 1 (one) year is 2008. Data website is the data today is November 2009, the majority of the company's website has not been updated for the 2009 period.

\subsection{Disclosure $3 R$ media}

Information on the 3Rs activities obtained through disclosure by the company. There are various ways for the company to inform the environmental awareness to stakeholders. Information on the environmental activities of the company can be expressed in a variety of media such as websites, annual reports, newsletters, magazines and other separate environmental report. Some previous researchers use environmental information based on annual reports as Wiseman (1982), Holland and Boon Foo (2003), and there are several other researchers who use environmental information from websites such as James (2006).

\section{a. Website}

Organizations or companies will increase the use of the website to include information related to their business, including information on the social and environmental ([1] in [28]). Starting mid-1999, almost all the major companies in the United States, Australia, 
Germany, Sweden and the UK use the website to provide financial information company (Lymer et al., 1999).

Disclosure of the company on the website provide benefits and also disadvantages. Benefits of the use of the website is the first, the website becomes the best platform to provide information both financial and non-financial (Wallman, 1995). Second, the Website becomes a communication tool that is superior to other media for dynamic information (updated), real-time data access and information, be able to download the data, and also as a means of direct contact between the company and stakeholders. Three, the information presented in the website are not based on the official contest rules, so that the company can control statements listed in the website according to their strategy. Cormier and Magnan (2006) showed that managers pay more attention to information on key stakeholders such stockholder as the basic determinant of strategy disclosure in their website.

Website has benefits, but also has some disadvantages compared to reporting companies by hardcopy. First, the possibility of information becomes overload [13], the Second, the lack of legislation regarding the website difficult to control the content of information used, and difficult for users to discern the quality of the information accessed from different sources, so this will increase the issue's security credentials [53]. Thirdly, manufacture and maintenance of the website can also be a cost for the company, as in Ashbaugh et al. (1999) found that the average cost to set up a website by its US amounted to $3.8 \%$ of total assets. So by looking at the aforementioned advantages and disadvantages are not all companies will benefit from the disclosure of information through the website.

So it can be said the fact that companies that disclose information via the website he probably because they derive a net benefit from the existence of the disclosure. When the benefits greater than the costs incurred, the company will voluntarily disclose such information as is said in the study Anggraini (2006). So that related to the disclosure regarding $3 \mathrm{R}$ activities of the company can be said that company will consider the costs and benefits to be gained by disclosing information regarding $3 R$ activities.

\section{b. Annual report}

The information will be used in this research is the information on the Reduce, Reuse and Recycle (3R) in Japan, the United Kingdom and Indonesia, so the information via the website in the sense of lacking sufficient for collecting information on the matter, 
because of differences in disclosure that exist in each country is different. So this research also used the annual report in order to obtain sufficient information.

Research Wiseman (1982) in Holland and Boon Foo (2003) said that the annual report is recognized as a medium of communication that is the main activity of the company. Barlett and Chandler (1997) also says that the company's financial statements is an important medium for communication between the company's financial management, shareholder and other surveys conducted despite stating that the financial statements are not very readable. Savage (1998) says that the financial statements are an important medium of communication to the stakeholders concerned, the legitimacy of the business environment activities.

According to the research of Thomas and Kenny (1996) annual report views 'least costly' but is most effective as a medium of communication. Wilmshurst and Frost (2000) said the annual report presents mandatory or voluntary information issued regularly and easily accessible. Tilt (1998) says that the financial statements are issued regularly requested by the legislature issued by all companies and easier to compare. Savage (1998), Savage and Cataldo (1999) said that more and more companies use the annual report to disclose information about social action, especially those relating to the environment. Tilt (1998) supports these findings that the annual report is the main medium for the disclosure of environmental information.

\section{c. Separate reports more}

There are several studies that criticize the media approach to the acquisition of information through annual reports. The criticism is based on the development of an environmental report in different companies by issuing separate statements other (separate report). Research Roberts (1991) and Unerman (2000) says that the focus of the annual report will produce a less complete picture with a growing number of reports. A major incentive for the other separate report is an annual report focus on the economic function of the company [13]. By issuing a separate report can provide a signal (possibly believe) that the companies concerned with CSR and CSR as important as the financial statements (Holland, 1993).

Research Holland and Boo Foo (2003) compared the environmental reporting company between UK and US. The main finding is the first company in the UK more that announce environmental reports separately or stand-alone or have a section which discusses a separate environment than companies in the US, while most companies US disclosure of environmental information in the management discussion and analysis, 
sections in the report Annually, the second company in the UK and the US looks different emphases to the items disclosed in its annual report, for example, an average $89 \%$ of companies in the UK disclose information on environmental award or certification is obtained, while the company's US only $33 \%$ do it. In contrast $72 \%$ of companies in the US disclose information on environmental regulations, while only $37 \%$ of companies in the UK which disclose it. Disclosure regarding environmental performance in annual reports or separate report is reflecting the level of Accountability, responsibility and corporate transparency to stakeholders. The report aims to establish good relationships and effective communication between the company and the public and stakeholders more about how the company has been integrating corporate social responsibility into every aspect of its operations (Darwin, 2007).

Based on the various aforementioned studies, this study uses all media are websites, annual reports, as well as separate reports such as CSR report, Environmental Report, SHE Report, Sustainability Report, Environmental Sustainability Report, Environmental \& Social Reporting for testing related to information $3 \mathrm{R}$, This is done to obtain complete information related to the $3 R$ activities of the company, so that the information is based on one of the media are not enough to give a complete picture of the activities of the company $3 \mathrm{R}$.

\section{Analysis}

\subsection{Source of data $3 R$ from website}

Sources of data on the 3 Rs can be found in the website of the company, but not all companies to disclose such information in the website. The information disclosed in the website has a different quality levels across the globe. Companies that disclose information about the environment in the website shows that the company cares about the environment. However, the level of concern varies for each company.

Disclosure of information on the website is composed into two: one, general information about the environment (merely preliminary or translation of a very brief and does not discuss the $3 \mathrm{R}$ ), two, the information is detailed (discussed in detail and separately on all environmental activities and environmental management including activity $3 R$ ). 
TABLE 1: General information environment on the website (non-reporting) (Source: information contained on the website).

\begin{tabular}{|l|c|c|c|}
\hline Country & Japan & English & Indonesia \\
\hline Total Company & 28 & 25 & 22 \\
\hline
\end{tabular}

\section{a. General information about the environment on the website}

In Table 1 seen from the 30 sample companies in each country, not all companies disclose general information about the environment at the website them. Disclosure of public information about the environment at the website of the company amounted to 28 Japanese companies, 25 companies for England and only 22 companies to Indonesia. In Japan and the UK, the company did not disclose environmental information in general provide information about the environment and the $3 \mathrm{Rs}$ in the annual report, or separate reports such as environmental sustainability report and environmental and social reporting which can be downloaded on the website them, while for the Indonesian state environmental information look not so into the company's attention so that information directly related to the $3 \mathrm{R}$ can be obtained from the annual report. General information about the environment on the website was obtained from column CSR, environmental/environmental and sustainability.

\section{b. Detailed information regarding $3 \mathrm{R}$ activities on the website}

Each company has a policy of disclosure that is different on the website them. In Japan, the company may disclose information about $3 R$ activity of more than 1 (one) column on the website them. This can be seen in Table 2, the total column disclosure in Japan totaled 40 column, which indicates that every 28 companies that disclose general information about the environment, revealing information about the $3 \mathrm{R}$ activity of more than one column. While in the UK, 25 companies that disclose general information about the environment, there are 23 companies that disclose detailed information on the website. While Indonesia of 22 companies that disclose general information about the environment only 2 companies that disclose detailed information on the 3 Rs in the website they are.

Every State has the distinction of putting environmental information and $3 R$. and each country has a level of disclosure and quality of disclosures different. In Table 2, it can be seen detailed information about the environment and the 3 Rs in the website was obtained from column CSR/Environmental, Sustainability, and Safe, Health and 
TABLE 2: 3R information on the website (non-reporting) (Source: information contained on the website).

Column
CSR
Environmental/SHE
Sustainability

\begin{tabular}{|c|} 
Japan \\
13 \\
20 \\
7 \\
\hline
\end{tabular}

English
$\begin{gathered}17 \\ 3 \\ 3\end{gathered}$

\begin{tabular}{c} 
Indonesia \\
1 \\
0 \\
1 \\
\hline
\end{tabular}
Total 31 23 11

Environment (SHE). Overall disclosure of CSR is mostly done in the column, then the environment and lastly sustainability. Disclosure in Japan company more columns Environmental (20), then CSR (13) and Sustainability (7). English country more disclosure on CSR column (17) and then SHE (3) and Sustainability (3). Countries Indonesia detailed disclosure on CSR (1) and Sustainability (1), while the more general disclosure on CSR.

Japan has a level of disclosure website with detailed information that is the highest compared to other countries, then follow with the UK and Indonesia last. Based on research Shbaugh et al. (1999) the disclosure of information on the website raises the cost, so that not all companies will benefit from the disclosure of information through the website. When benefits are greater than the costs incurred, the company will voluntarily disclose such information (Anggraini, 2006). Thus company will consider the costs and benefits to be gained by disclosing information regarding $3 \mathrm{R}$ activities.

\subsection{Sources of data $3 R$ of the annual report and other separated obtained from the website}

All companies in Japan, the UK and Indonesia disclose information about environmental and $3 R$ in the annual report. The information provided not only information from the company's annual report, but the company also revealed information about the environment and the $3 \mathrm{Rs}$ in other separate reports.

Apart from the website, information about activity $3 \mathrm{R}$ obtained from annual reports (in which there is a discussion of the CSR/Sustainability/Environmental), and a separate report such as CSR report, Environmental Report, SHE Report (for UK), Sustainability Report, Environmental Sustainability Report, Environmental \& Social Reporting. With the level of disclosure that is reflected in Figure 4 (http://www.denvergov.org).

From Figure 4.1., the overall disclosure of the most widely performed in the CSR report (22), and Sustainability Report (10), and the Environmental Report (6). A separate report on the State of Japan conducted CSR Report (11), environmental and social 
reporting (7), sustainability report (4), environmental report (3), and environmental sustainability report (1). Britain, the CSR Report (11), Sustainability Report (3), SHE Report (3). And Indonesia, the Sustainability Report (3).

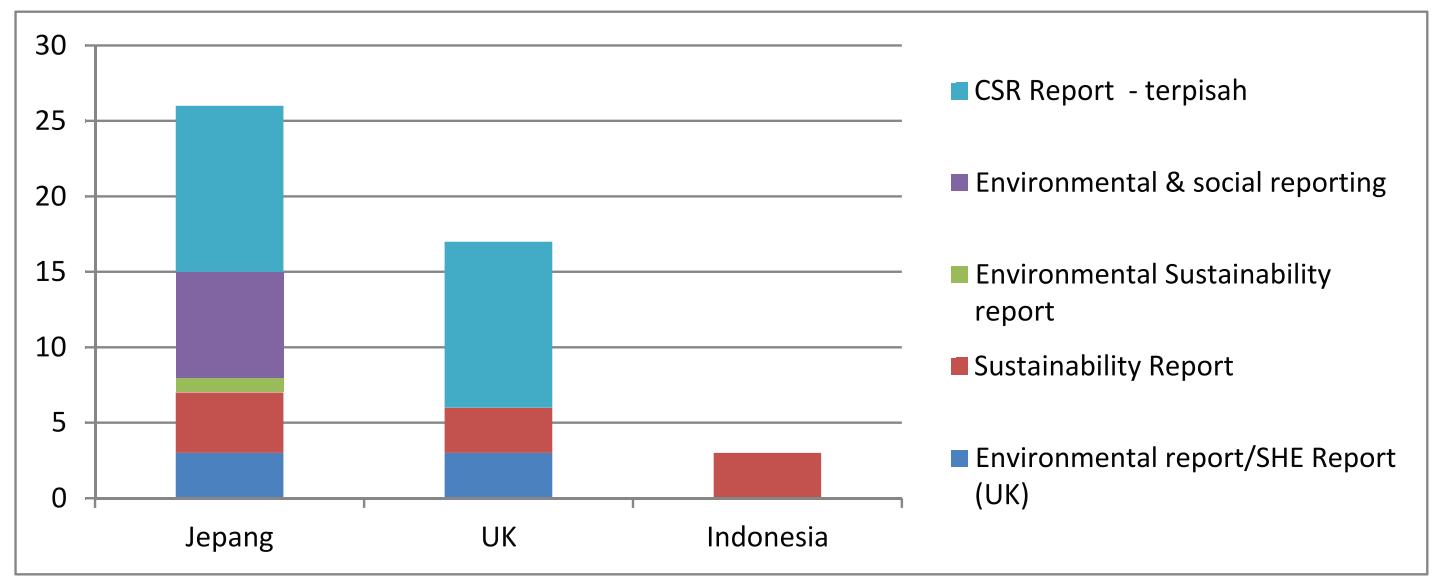

Figure 1: Disclosure level 3R on separated reports. Source: A separate report can be downloaded from the website company.

Japan has the highest level of disclosure separate report later followed by the UK and Indonesia. A high level of disclosure that is caused by two things: first, the high concern for the environment, the environmental issues of major concern and the main basis in running the business. Concern for the environment has become an integral part in the company's business activities are reflected in the high level $3 R$ activities of the company, as happened in Japan. More will be discussed in the analysis of the research results at the end of this chapter. It also addresses the research objectives of the 2nd. Secondly, with regard to the existence of information asymmetry theory and legitimacy theory as discussed in Chapter 2.

The varying degree of disclosure by the company regarding $3 \mathrm{R}$ activities according to what is said in the research Gray et al. (1995) that corporate social and environmental reporting possessed many synonym including corporate social reporting (CSR), corporate social disclosure, disclosure and reporting social responsibility and so forth.

\subsection{Disclosure quality $3 R$ activities}

This study did not examine further the quality of disclosure. Based on research conducted by Holland and Boon Foo (2003) the quality of disclosure about the environment is very diverse, research, Holland and Boon Foo (2003) found the diversity of quality of disclosures made to the UK and US, the overall quality of disclosure about the environment to the UK and US still categorized as 'low'. So is the case with this study, the 
difference in quality of disclosure in Japan, the United Kingdom and Indonesia related to environmental matters and $3 \mathrm{R}$ activities. Based on observations of the author, the quality can be divided into two (2): first, judging from the number of reports issued on the environment, Japan has a better quality than the UK and Indonesia. Second, judging from the contents. each country has a purpose different disclosure further described in Table 3.

TABLE 3: Related Disclosures quality 3R.

\begin{tabular}{|c|c|c|c|}
\hline Information & Japan & English & Indonesia \\
\hline $\begin{array}{l}\text { Obtaining } \\
\text { information } \\
\text { and content } \\
\text { related to } \\
\text { environmental } \\
\text { information } \\
\text { and } 3 R\end{array}$ & $\begin{array}{l}\text { - In the website, the } \\
\text { information is very } \\
\text { complete environment. } \\
\text { - All information can be } \\
\text { obtained easily (such as } \\
\text { annual reports, } \\
\text { sustainability report, } \\
\text { environmental report). } \\
\text { - The company has } \\
\text { a website of its own } \\
\text { specifically addressing } \\
\text { environmental and } 3 R \text {. } \\
\text { - The annual report } \\
\text { summarizes the activities } \\
\text { of what has been } \\
\text { discussed in a separate } \\
\text { environmental report and } \\
\text { a summary descriptions of } \\
\text { websites } \\
\text { - Have a separate report, a } \\
\text { report sustainability } \\
\text { report, environmental report }\end{array}$ & $\begin{array}{l}\text { - In the website, } \\
\text { information about the } \\
\text { environment is more } \\
\text { common } \\
\text { - Discussion of } \\
\text { environmental information } \\
\text { and environmental } \\
\text { management systems } \\
\text { (including } 3 R \text { ) are } \\
\text { discussed in detail in the } \\
\text { annual report. } \\
\text {-Have a separate report } \\
\text { that SHE report, } \\
\text { environmental report and } \\
\text { cSR report }\end{array}$ & $\begin{array}{l}\text { - In the website, very few } \\
\text { companies that disclose } \\
\text { information about } \\
\text { environmental and general } \\
\text { nature only } \\
\text { - Information is difficult to } \\
\text { obtain (annual reports, and } \\
\text { other reports) } \\
\text { - Environmental } \\
\text { information obtained } \\
\text { through annual reports }\end{array}$ \\
\hline Information & Japan & English & Indonesia \\
\hline $\begin{array}{l}\text { Environmental } \\
\text { information }\end{array}$ & $\begin{array}{l}\text { More on environmental } \\
\text { management } \\
\text { (environmental } \\
\text { management system(3R)), } \\
\text { detailing all activities of } \\
\text { the company } 3 \mathrm{R} \text {, } \\
\text { accompanied by pictures, } \\
\text { charts and figures. }\end{array}$ & $\begin{array}{l}\text { Disclosure of } \\
\text { environmental } \\
\text { management systems ( } 3 R) \\
\text { but not in detail that is not } \\
\text { accompanied by a picture } \\
\text { and chart6 }\end{array}$ & $\begin{array}{l}\text { More on imagery } \\
\text { (donations, other CSR } \\
\text { activities) instead of } \\
\text { system } \\
\text { management environment }\end{array}$ \\
\hline $\begin{array}{l}\text { Benefit for the } \\
\text { company }\end{array}$ & $\begin{array}{l}\text { More on efficiency, } \\
\text { conservation of nature and } \\
\text { image }\end{array}$ & $\begin{array}{l}\text { Efficiency (but not a lot of } \\
\text { discussion), nature } \\
\text { conservation, image }\end{array}$ & Imagery \\
\hline $\begin{array}{l}\text { Benefit for the } \\
\text { environment }\end{array}$ & $\begin{array}{l}\text { Climate change, } \\
\mathrm{CO}_{2} \text {, conservation natural } \\
\text { resources }\end{array}$ & Climate change and $\mathrm{CO}_{2}$ & $\begin{array}{l}\text { More on Social, a little } \\
\text { about climate change (only } \\
\text { a few companies) }\end{array}$ \\
\hline $\begin{array}{l}\text { Vision and } \\
\text { mission }\end{array}$ & More on the environment & Implicit & $\begin{array}{l}\text { Not emphasize the } \\
\text { environment }\end{array}$ \\
\hline
\end{tabular}




\section{Conclusion Research}

Information disclosure data sources $3 R$ activities can be found on the website, annual report and other reports such as separate CSR report, Environmental Report, SHE Report (for UK), Sustainability Report, Environmental Sustainability Report, Environmental \& Social Reporting. $3 \mathrm{R}$ activities level and quality of information disclosure $3 \mathrm{R}$ activities on a sample of companies in Japan is the highest, followed by the UK and Indonesia last. Personality reveals that voluntary causing the possibility of hidden information that does not exist in the media used by the author so that the data becomes less complete.

Further research can increase the number of samples the state and the number of samples in each country, as well as test other industries to gain a deep understanding of the 3 Rs activities that can be generalized. In terms of time, can be expanded to see the impact of the 3 Rs in the short and long term

Further research can identify the location of the $3 \mathrm{R}$ activity disclosure in the annual report of the UK example $3 \mathrm{R}$ more elaboration on the part of company strategy, CSR, review operation or management's discussion and analysis, and so forth.

1 http://www.denvergov.org

2 Kenjiro et al., Nd (working paper)

3 www.cic-fcgi.org/news

${ }^{4}$ Source: information contained on the website

5 Source: information contained on the website

${ }^{6}$ Consistent with the findings of Holland and Boon Foo (2003)

\section{References}

[1] Adam, C. \& Forst, G. 2004, The Development of Corporate Websites and Implications for Ethical, Social and Environmental Reporting through these Media. The Institute of Chartered Accountonts of Scotland, Scotland.

[2] Adams, C. A., Hill, W.-Y., \& Roberts, C. B. 1998. Corporate social reporting practices in Western Europe. British Accounting Review, March, Vol. 30, pp. 1- 21.

[3] Aerts, W., Cormier, D., Magnan, M. 2006. Intra-Industry Imitation in Corporate Environmental Reporting: An International Perspective. Journal of Accounting and Public Policy. Vol. 25, pp. 299-331.

[4] Ashbaugh, H., Johnstone, K.M., Warfield, T. D. 1999. Corporate Reporting on The Internet. Accounting Horizons, Sept., pp. 241-257. 
[5] Brown, N., Deegan, C., 1998. The Public Disclosure Of Environmental Performance Information-A Dual Test Of Media Agenda Setting Theory And Legitimacy Theory. Accounting And Business Research. Vol. 29, No. 1, pp. 21-41.

[6] Chow, C.W., Wong-Boren, A. 1987. Voluntary Financial Disclosure by Mexican Corporations. The Accounting Review. Vol. 62, No. 3, pp. 533-541.

[7] Christiansen, G.B., \& Haveman, R.H. 1981. The contribution of environmental regulations to the slowdown in productivity growth, Journal of Environmental Economics and Management, 8, 381-390.

[8] Conrad, K., \& Morrison, C.J. 1989. The impact of pollution abatement investment on productivity change: An empirical comparison of the US, Germany and Canada, Southern. Economic Journal, 55, 684-698.

[9] Cormier, D., \& Magnan, M. 2003. Environmental Reporting Management: A Continental European Perspective. Journal of Accounting And Public Policy. Vol. 22, pp. $43-62$.

[10] Cormier, D., \& Magnan, M. 2006. Corporate Environmental Disclosure, Financial Markets And The Media: An International Perspective. Walter Aerts. Foculty of Applied Economics University of Antwerp Belgium. February. Working Paper.

[11] Craig, R dan J. Diga. 1998. Corporate Accounting Disclosure in ASEAN. Journal of International, Financial Management and Accounting. Vol. 9, No. 3, pp. 246-274

[12] Darnall, Nicole. 2008. Regulatory Stringency, Green Production Offsets and Organizations' Financial Performance. Preprint to be published in Public Administration Review.

[13] Debreceny R. G. Gray dan A. Rahman. 2002. The Determinants of Internet Financial Reporting. Journal of Accounting and Public Policy. Vol. 21, Pp. 371-394.

[14] Deegan, C., Gordon, B., 1996. A Study Of The Environmental Disclosure Policies Of Australian Corporations. Accounting And Business Research. Vol. 26, No. 3, pp. 187199.

[15] Deegan, C., Rankin, M., 1996. Do Australian Companies Report Environmental News Objectively? Accounting, Auditing And Accountability Journal. Vol. 9, No. 2, pp. 50-67.

[16] Desimone, L., Popoff, F., 1997. Eco-Efficiency: The Business Link To Sustainable Development. MIT Press, Cambridge, Ma.

[17] Dowling, J., \& Pfeffer, J. 1975. Organizational legitimacy: Social values and organizational behavior. Pacific Sociological Review, Vol. 18, No. 1, pp. 122-138.

[18] Dunlapp, R., Gallupp, G. H. and Gallupp, A. M. 1992. The Health of the Planet Survey. The George H. Gallupp International Institute, Princeton. 
[19] Gamble, G., Hsu, K., Kite, D., Radtke, R., 1995. Environmental Disclosures In Annual Reports And 10ks: An Examination. Accounting Horizons, Vol. 9, No. 3, pp. 34-54

[20] Gray, R., Kouhy, R., \& Lavers, S. 1995a., "Corporate Social And Environmental Reporting: A Review Of The Literature And A Longitudinal Study Of UK Disclosure", Accounting Auditing \& Accountability Journal, Vol. 8, No. 2, pp. 47- 77.

[21] Gray, R., Owen, D. \& Adams, C. 1996, Accounting And Accountability: Changes And Challenges In Corporate Social And Environmental Reporting. Prentice Hall, London.

[22] Gray, R., Javad, M., Power, D., 2001. Social And Environmental Disclosure And Corporate Characteristics: A Research Note And Extension. Journal of Business Finance And Accounting (April/May), pp. 327-356.

[23] Guthrie, J., \& Parker, L. 1990. Corporate Social Disclosure Practice: A Comparative International Analysis. Advances In Public Interest Accounting, Vol. 3, pp. 159- 175.

[24] Hackston, D., \& Milne, M. 1996. Some Determinants Of Social And Environmental Disclosures In New Zealand Companies. Accounting Auditing \& Accountability Journal, Vol. 9, No. 1, pp. 77- 108.

[25] Halme, M., Huse, M., 1997, The Influence Of Corporate Governance, Industry And Country Factors On Environmental Reporting. Scand. Journal of Management, Vol. 13, No. 2, pp. 137-157.

[26] Harte, G. and Owen, D. 1991. Environmental Disclosure in The Annual Reports of British Companies: A Research Note. Accounting, Auditing and Accountability Journal. Vol. 4, No. 3, pp. 51-61.

[27] Holland, L., Boon Foo, Y. 2003. Differences In Environmental Reporting Practices In The UK And The US: The Legal And Regulatory Context. The British Accounting Review. Vol. 35, Pp. 1-18.

[28] James, Suresh dan Leanne, 2006. Social and environmental reporting: The Australian Food and Beverage Industry. School of Business Building (H69) The University of Sidney. Working Paper.

[29] Jensen, M.C., Meckling, W.H., 1976. Theory of The Firm: Managerial Behaviour, Agency Costs And Ownership Structure. Journal of Financial Economics October.

[30] Kalla, 2006. EBAR Edisi 3, September-December 2006.

[31] Kastaman, Roni \& Nurpilihan, 2004. Pola produksi dan konsumsi yang berkelanjutan, seminar ilmiar dies natalis Universitos Padjajaran ke 47.

[32] Khanna, M., \& Damon, L.A. 1999. EPA's Voluntary 33/50 Program: Impact on toxic releases and economic performance of firms, Journal of Environmental Economics \& Management, 37, 1-25. 
[33] Lang, M., Lundholm, R., 1993. Cross-Sectional Determinants of Analyst Ratings of Corporate Disclosures. Journal of Accounting Research, Vol. 31, No. 2, pp. 246-271.

[34] Lave, L.B. 1973. The economic costs of air pollution, The Economics of Environmental Problems, 58, 19-35.

[35] Li-Chin Jennifer Hoo and Martin E. Taylor. 2007. An Empirical Analysis of Triple Bottom-Line Reporting and its Determinants: Evidence from The United States and Japan. Journal of International Financing Management and Accounting, Vol. 18, No. 2.

[36] Meek, G. K., Roberts, C. B., \& Gray, S. J. 1995. Factors Influencing Voluntary Annual Report Disclosures By U.S., U.K. And Continental European Multinational Corporations. Journal of International Business Studies, pp. 555- 574 (3rd Quarter).

[37] Noe, C., 1999. Voluntary Disclosures and Insider Transactions. Journal of Accounting and Economics, Vol. 27, pp. 305-327.

[38] Nurhayati, Ratna, Alistair Brown, Greg Dan Tower. 2006. Natural Environment Disclosures of Indonesian Listed Companies. Paper Submission AFAANZ Conference, July, 2006. Wellington, New Zealand. Working paper.

[39] Patten, D. 1991, "Exposure, Legitimacy and Social Disclosure", Journal of Accounting and Public Policy, Vol. 10, No. 3, Pp. 297-308.

[40] Patten, D. 1992. Intra-Industry Environmental Disclosures In Response To The Alaskan Oil Spill: A Note On Legitimacy Theory. Accounting, Organizations, And Society, pp. 471-475.

[41] Porter, M., \& Van Der Linde, C. 1995. Toward A New Conception Of The EnvironmentCompetitiveness Relationship. Journal of Economic Perspectives, Vol. 9, No. 4, pp. 97-11

[42] Rivera, J. 2002. Assessing a voluntary environmental initiative in the developing world: The Costa Rican certification for sustainable tourism, Policy Sciences, 35, 333360.

[43] Roberts, R. W. 1992. Determinants Of Corporate Social Responsibility Disclosure: An Application Of Stakeholder Theory. Accounting, Organization and Society, Vol. 17, pp. $595-612$

[44] Russo, M.V., \& Fouts, P.A. 1997. A Resource-based perspective on corporate environmental performance and profitability, Academy of Management Journal, 40, 534-559.

[45] Salter, S., \& Niswander, F. 1995. Cultural Influence On The Development of Accounting Systems Internationally: A Test Of Gray's (1988) Theory. Journal of International Business Studies, pp. 379- 397. 
[46] Schmidt, G. (2001): Auf dem Weg zur Kreislaufwitschaft? Japans Umweltpolitik nach der Verwaltungsreform. In: Pohl, M.; Wiecorek, I. (Eds.), Japan 2000/2001. Politik und Wirtschft. Institut Fur Asienkunde Hamburg, pp. 253-268

[47] Sinkin, C., Charlotte J. Wright, Royce D. Burnet. 2008. Eco-Efficiency And Firm Value. Journal of Accounting And Public Policy. Vol. 27. pp. 167-176

[48] Vanstraelen A. M. Zarzeski dan S. Rabb. 2003. Corporate Non-Financial Disclosure practices and Financial Analyst Forecast Ability-Across Three European Countries. Journal of International Financial Management and Accounting. Vol. 14. No. 3, Pp. 249278.

[49] Walden, W. D, \& Schwartz, B. N. 1997. Environmental disclosures and public policy pressures. Journal of Accounting and Public Policy, Vol. 16, pp. 125-154.

[50] Walden, W. D, \& Schwartz, B. N. 1997. Environmental disclosures and public policy pressures. Journal of Accounting and Public Policy, Vol. 16, pp. 125-154.

[51] Williams, S. M. 1999. Voluntary Environmental And Social Accounting Disclosure Practice In The Asia-Pacific Region: An International Empirical Test of Political Economy Theory. The International Journal of Accounting, Vol. 34, pp. 209-238.

[52] Wiseman, J. 1982. An Evaluation Of Environmental Disclosures Made In Annual Reports. Accounting Organizations and Society, Vol. 7, pp. 553-563

[53] Xiao, J. Z., Jones M. J. Lymer. A., 2002. Immediate Trends in Internet Reporting. European Accounting Review, Vol. 11 (2), pp. 245-275.

[54] Europa. (n.d.). Summaries of EU Legislation. Waste Management.

[55] http://europa.eu/legislation_summaries/environment/waste_management/ index_en.htm

[56] Kementerian Lingkungan Hidup. www.menlh.go.id

[57] Ministry of Environment, Japan. The World Summit on Sustainable Development (WSSD). (n.d.). Joint Plan of Implementation specifically endorses the $3 R$ policy approach as a means to achieve sustainable consumption and production. Para 22. http://www.env.go.jp. 